\title{
FISHING THE THAMES ESTUARY \\ IN THE LATER MIDDLE AGES: ENVIRONMENT, TECHNOLOGY AND THE METROPOLITAN \\ MARKET FOR FISH C. 1250-1550
}

\author{
James A. Galloway \\ INDEPENDENT SCHOLAR \\ IRELAND
}

Date of receipt: $6^{\text {th }}$ of September, 2019

Date of acceptance: $9^{\text {th }}$ of October, 2019

\section{Abstract}

The estuary and tidal river of the Thames in south-eastern England were home to active commercial fisheries in the later middle ages. Despite conflicts over navigation, especially related to the use of fixed fish-weirs, the estuary supplied large quantities of fish to the London market. The importance of Thames fish to Londoners' diet emerges from documentary and archaeological evidence. These fisheries remained important throughout the period 1250-1550 and were not destroyed by the rise of large-scale trade in preserved fish from more distant waters.

\section{KeyWords}

Thames Estuary, Fishing, Coastal Environment, Medieval London, Diet.

\section{Capitalia verba}

Aestuarium Tamesis, Piscatio, Circumiecta litoralia, Londinium Mediaevale, Diaeta. 


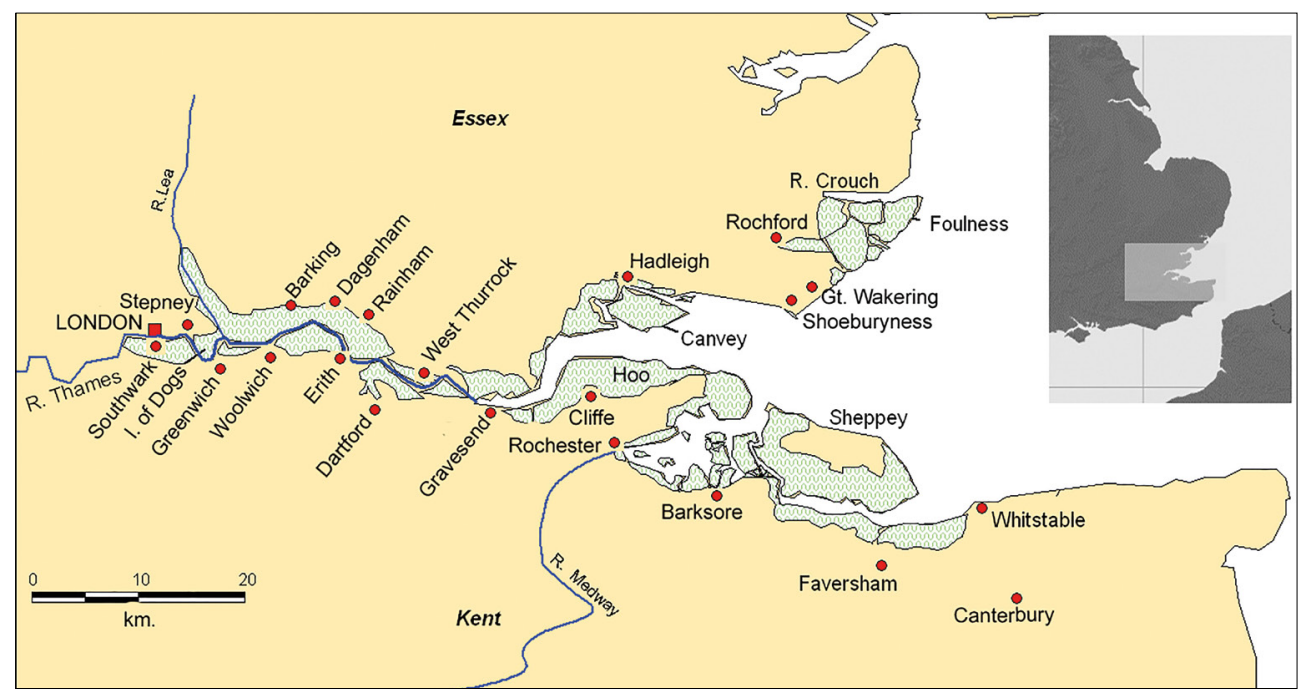

Illustration 1. The Thames Estuary: Location Map. Note: Areas of alluvial marshland are shown IN GREEN. MAP PROVIDED By THE AUTHOR.

English inshore and estuarine fisheries ${ }^{1}$ have received much less attention from historians than the commercial sea fisheries of the high and later Middle Ages, which have been the subject of a number of important studies in recent decades. ${ }^{2}$ The most notable exception is Harold Fox's pioneering study of the south Devon coast, which includes consideration of all aspects of fishing practice in that southwestern county. ${ }^{3}$ The present paper attempts a less ambitious overview of the later medieval exploitation of the fisheries of the estuary of the River Thames in southeastern England. It reviews the species caught around the estuary between the

1. Versions of this paper were presented to a meeting of the Diet Group, University of Oxford, in November 2014 and at the European Society for Environmental History's biennial conference held in Versailles in July 2015. I am grateful to participants at both these meeting for their valuable comments and suggestions. I am also grateful for Laura Wright for her comments of an earlier draft of this paper. Any remaining errors are of course my own. Used abbreviations: CCA, Canterbury Cathedral Archives; ERO, Essex Record Office; TNA, The National Archives.

2. E.g. Starkey, David J.; Reid, Chris; Ashcroft, Neil, eds. England's Sea Fisheries: The Commercial Sea Fisheries of England and Wales since 1300. London: Chatham, 2000: 18-44; Kowaleski, Maryanne. "The commercialisation of the sea fisheries of medieval England and Wales". International Journal of Maritime History, 15 (2003): 177-231; Kowaleski, Maryanne. "The early documentary evidence for the commercialisation of the sea fisheries in medieval Britain", Cod and Herring: the Archaeology and History of Medieval Sea Fishing, James H. Barrett, David C. Orton, eds. Oxford: Oxbow Books, 2016: 23-41; for a short overview see Galloway, James A. "Fishing in medieval England", The Sea in History: the Medieval World, Michel Balard, ed. Woodbridge: Boydell, 2017: 629-642

3. Fox, Harold. The Evolution of the Fishing Village: Landscape and Society along the South Devon Coast, 10861550. Oxford: Leopard's Head, 2001. 
thirteenth and early sixteenth centuries, identifies the principal centres of fishing activity and considers the technology employed. The city of London's attempts to regulate the estuarine fisheries are examined, and the importance of the London market assessed. Finally, the implications of the rise in the bulk trade in preserved fish for the fortunes of the estuarine fisheries are discussed. The paper is principally based upon published documentary sources generated by the City of London ${ }^{4}$ and the English crown, supplemented by published, online and manuscript documents relating to tenure, courts and manorial organisation in the Thames area; reference is also made, where relevant, to published archaeological findings.

The Thames Estuary is a coastal plain estuary, formed by marine flooding of a pre-existing river valley since the end of the last Ice Age. It forms one of a number of such estuaries in England -others include the Severn, Humber and Deecharacterised by their shallow and sediment-filled character, with extensive areas of mud-flat and saltmarsh. ${ }^{5}$ The Thames Estuary comprises the inner estuary, that section of the tidal river between the city of London and Gravesend in Kent, at which point it is nearly a kilometre wide, and the funnel-shaped outer estuary, which widens to $20 \mathrm{~km}$, facing the European mainland. The tidal range of most of the Thames Estuary today falls within the macrotidal category (4-6 m). In central London the range on spring tides exceeds $7 \mathrm{~m}$, but in the past it was significantly less. In the early middle ages the tidal range at London has been estimated at only about $1.5 \mathrm{~m}$, increasing to $3 \mathrm{~m}$, or perhaps somewhat more, in the $14^{\text {th }}$ century. ${ }^{6}$

Circulation in the Thames Estuary can be characterised as partially mixed, in that sea-water inflow and fresh-water discharge are broadly similar and in a constant process of mixing, although surface waters tend to be less saline than bottom waters at any given point. ${ }^{7}$ Today the tidal head, the furthest point to which tidal effects are normally felt, lies at Teddington Lock, some $35 \mathrm{~km}$ upriver from central London. The precise location of the tidal head in the later middle ages is uncertain. However,

4. The most frequently referred to here are Calendar of Letter-Books Preserved among the Archives of the Corporation of the City of London at the Guildhall, Letter Books A to L, ed. Reginald R. Sharpe. London: J. E. Francis, 1899-1912, 11 vols.; Calendar of select pleas and memoranda of the city of London, 1381-1412, ed. Arthur H. Thomas. Cambridge: Cambridge University Press, 1932; Memorials of London and London Life in the XIIIth, XIVth, and XVth Centuries, ed. Henry T. Riley. London: Longmans Green, 1868. Any research into the medieval Thames is also hugely indebted to Laura Wright's study of medieval vocabulary, which presents and analyses a mass of material relating to terms for Thames structures, organisms, personnel and activities, drawn from a wide variety of London manuscript sources. Laura Wright. Sources of London English: Medieval Thames Vocabulary. Oxford: Clarendon Press, 1996.

5. See the chapter "The estuarine environment" in McLusky, Donald; Elliott, Michael. The Estuarine Ecosystem: Ecology, Threats and Management. Oxford: Oxford University Press, 2004: 1-18.

6. Milne, Gustav. The Port of Medieval London. Stroud: Tempus, 2003: 144-146. The suggestion that the inner estuary tidal range may have amounted to as much as $5 \mathrm{~m}$ c. 1200 is made in Goodburn, Damian; Davis, Simon. "Two new Thames tidal mill finds of the 690s and 1190s and a brief update on archaeological evidence for changing medieval tidal levels", Tides and Floods: New Research on London and the Tidal Thames from the Middle Ages to the Twentieth Century. Galloway, James A. ed. London: Institute of Historical Research, 2010: 12. Extreme tides are today regulated by the Thames and Barking Barriers, flood defences constructed in the 1970s and 80s.

7. McLusky, Donald; Elliott, Michael. «The estuarine environment...» 
it is clear that the massive structure of the stone-built London Bridge, completed at the beginning of the thirteenth century, acted as a partial barrier or dam against both tidal influence and the penetration of salt water. ${ }^{8}$ In periods of exceptionally low or high fresh-water inflow, or during storm surge conditions, this damming effect might be overcome, but in this paper I will follow medieval usage and take the Bridge to form the point at which major tidal influence ceased and at which brackish water gave way to fresh water. The Thames Estuary is therefore defined here as running from the Bridge eastwards to the mouth of the estuary, at Foulness Island in Essex and Thanet in Kent, where the open North Sea begins (see illustration 1).

The Thames Estuary, although in form similar to other east-facing estuaries of England and Scotland, had a unique character given to it by the human geography of the medieval period. At the lowest bridging point of the Thames was located by far the largest city of Britain and Ireland. London, with perhaps 80,000 inhabitants c. 1300, was at least three times bigger than any other urban centre in England, Scotland, Wales or Ireland and rivalled some of the major cities of continental Europe. It constituted a cultural, political and economic centre which increasingly concentrated power, wealth and trading networks upon itself. England's overseas trade came to be more and more focused upon London during the later middle ages, most of it passing through the Thames Estuary, and internal commerce also became increasingly influenced by London as a centre of consumption, production and redistribution. The city came to exercise a powerful influence upon its surrounding region, moulding agriculture, land-use and the exploitation of natural resources. ${ }^{9}$

Within the Thames basin, reclamation of alluvial marshlands and their conversion into productive arable and pasture land proceeded rapidly in the twelfth and thirteenth centuries, in part a response to the city's growing demands for food. These processes culminated c. 1300 as the population of London and its region reached their medieval peak. Embankment and reclamation reduced the extent of the inter-tidal area; this had implications for the fish populations of the estuary, as salt-marsh provides an important nursery habitat for many species. The economic changes of the post-Black Death period also had consequences for the estuarine ecosystem; some areas of reclaimed marsh reverted to inter-tidal conditions due to storm flooding and the reduced incentive to maintain sea- and river-defences in an era of depressed agricultural prices. The regenerating estuarine saltmarshes of the later middle ages were rapidly colonised by fish; fish nurseries and new fishing

8. Watson, Bruce; Brigham, Trevor; Dyson, Tony. London Bridge: 2000 Years of a River Crossing. London: Museum of London Archaeology Service, 2001: 116, 161-162. The bridge was 276 metres long, and was supported by 19 piers set amidst "starlings", broad boat-shaped bulwarks. The resulting channels through which the river flowed were narrow and the flow extremely rapid, making navigation hazardous and creating the partial damming effect.

9. Galloway, James A. "Town and Country in England 1300-1570", Town and Country in Europe 13001800, Stephan R. Epstein, ed. Cambridge: Cambridge University Press, 2001: 106-131; Keene, Derek, "Medieval London and its supply hinterlands". Regional Environmental Change, 12 (2012): 263-281; Kowaleski, Maryanne. "The maritime trade networks of medieval London", The Routledge Handbook of Medieval Trade around Europe 1300-1600, Wim Blockmans; Mikhail Krom; Justyna Wubs-Mrozewicz, eds. London-New York: Routledge, 2017: 383. 
grounds can be seen to have emerged at Barking, Erith and other locations, in a dynamic process of humanenvironmental interaction. These developments have been traced in some detail elsewhere. ${ }^{10}$

\section{Fish species ${ }^{11}$}

The complex patterns of circulation and salinity in the Thames Estuary, together with the numerous human interventions in the aquatic and littoral environments, created challenging conditions for fish and other fauna. The fauna of estuaries is normally categorised as an impoverished version of marine fauna, meaning that significantly fewer species are found there than in adjoining areas of open sea, because many species are unable to tolerate the lower but fluctuating salinity levels. In addition, few fresh-water species are able to penetrate far into the tidal zone as the salinity increases. Nevertheless, in the late $20^{\text {th }}$ century 112 species of fish were known to inhabit or traverse the tidal stretches of the river Thames and the inner estuary, some species being present in great numbers. ${ }^{12}$ This reflected the remarkable resurrection of a riverine and estuarine ecosystem which had been virtually dead between the mid- $19^{\text {th }}$ and mid- $20^{\text {th }}$ centuries as a result of urban and industrial pollution, but which had been progressively cleaned up,

10. Galloway, James A. "Storm flooding, coastal defence and land use around the Thames Estuary c.1250-1450". Journal of Medieval History, 35 (2009): 171-188; Galloway, James A. “'Piteous and grievous sights': the Thames marshes at the close of the Middle Ages", Tides and Floods, James A. Galloway ed. London: Institute of Historical Research, 2010: 15-27; Galloway, James A. “Tempests of weather and great abundance of water: the flooding of the Barking marshes in the later middle ages", London and Beyond: Essays in Honour of Derek Keene, Matthew Davis, James A. Galloway, eds. London: Institute of Historical Research, 2012: 67-83.

11. For the Latin names of fish species mentioned in the text of the present paper, see Appendix.

12. Thomas, Myles. "Temporal changes in the movements and abundance of Thames estuary fish populations", A Rehabilitated Estuarine Ecosystem: the Environment and Ecology of the Thames Estuary, Martin J. Attrill, ed. New York: Springer, 1998: 115-140. 
to the extent that migratory salmon had returned to the Thames by the 1970s. ${ }^{13}$ Many other species of commercial or recreational value inhabit or pass through the Thames estuary today, including herring, smelt, flounder, sole and whiting.

Documentary sources allow us in part to reconstruct the fauna of the estuary in the middle ages, although the record is necessarily biased towards species considered valuable for consumption and exchange at the time. Archaeology contributes vital evidence on the species consumed in London and at other places around the estuary; although here the problem is that the fish consumed may have come from far away, rather than from the estuary itself. Isotopic evidence is beginning to address this issue, although as yet only at a fairly broad-brush level (see below). When the $12^{\text {th }}$ century writer Fitz-Stephen turned to the Thames in his encomium of the city of London, he noted its importance for fish as well as for trade. ${ }^{14}$ Later writers were more specific: in the $16^{\text {th }}$ century William Harrison rhapsodised over the "fat and sweet salmons daily taken in this stream" and the "store also of barbels, trouts, chevens [chub], perches, smelts, breams, roaches, daces, gudgeons, flounders, shrimps, eels, etc. commonly to be had therein", thus emphasising migratory and brackish-water tolerant species as well as freshwater ones. ${ }^{15}$ A century earlier William Worcestre had described the island of Foulness, at the mouth of the Estuary, as abounding in oysters, mussels and fish. ${ }^{16}$

Perhaps more valuable for indicating the species considered of economic importance to contemporaries are the voluminous records generated by the city of London, the English crown, and the possessors of property around the estuary in the later middle ages. It is of course vital to distinguish between fish which were caught or observed in the tidal river Thames and its estuary and those which were being brought to London from more distant waters.

Ordinances seeking to regulate fishing seasons and the size of mesh used in fishing nets in the stretches of the river and estuary over which London claimed jurisdiction, ${ }^{17}$ enrolled in the late thirteenth century but with later additions and

13. Wheeler, Alwyne. The Tidal Thames. The History of a River and its Fishes. London: Routledge 8 Kegan Paul, 1979.

14. Keene, Derek. "Issues of water in medieval London", Urban History, 28 (2001): 161.

15. Harrison, William. The Description of England: The Classic Contemporary Account of Tudor Social Life, ed. George Edelen. Washington: Folger Shakespeare Library, 1994 (first edition: 1968): 419. Flounders tolerate a wide variety of salinity levels and are found in freshwater, brackish estuaries and fully maritime coastal waters from the tideline to a depth of about 55 metres. Smelt are migratory living in the outer estuaries of the Thames and other rivers, moving further upriver in late winter before spawning in spring in areas of tidal influence but low salinity. Eels, being catadromous, breed and spawn in the sea moving to freshwater to grow. In the Thames they make their way upriver between March and May or June. These characterisations are taken from Wheeler, Alwyne. Tidal Thames..., and Wheeler, Alwyne. "The origin and distribution of the freshwater fishes of the British Isles", Journal of Biogeography, 4 (1977): $1-24$.

16. Worcestre, William. Itineraries [of] William Worcestre, ed. John Harvey. Oxford: Clarendon Press, 1969: 145 .

17. In the later middle ages London asserted authority over the river from Staines to the west, some $65 \mathrm{~km}$ upriver, to the Yantlet Creek and the mouth of the River Medway in the outer estuary. Keene, Derek. “Issues of water...": 167. 
annotations, refer to roaches, lamperns and lampreys, smelt, and salmon. ${ }^{18} \mathrm{~A}$ version of the oath of the London Fishmongers, dating from the $15^{\text {th }}$ century, refers to "fysshe of temise [Thames] that is to wytte smelt, rochis [roaches] or floundris [flounders]." ${ }^{19}$ In 1386 fry of roach, lampern, flounder and dace were found to have been illegally trapped east of London Bridge. An enquiry into fishing for smelt and gudgeon east of the bridge was held the same year, and was told also of the "destruction" of salmon and sturgeon by fishing weirs. ${ }^{20}$ Sturgeon were, by the later middle ages, vanishingly rare in English waters, but in 1316 a London fisherman presented King Edward II with a specimen caught in the tidal Thames at Woolwich. ${ }^{21}$ A 1421 petition to parliament by the the fishermen of the river Thames sought action to prevent the destruction of the "fry of salmon, trout, mullet, and other fish". ${ }^{22}$ Fry were used inter alia as bait for cod (by line-fishing) and eels (in traps). ${ }^{23}$ In 1486 the fishers of the Thames and its tributaries were said to daily take barbel, flounder, roach, pike, tench and other fish in their nets and "engynes" (weirs or traps). ${ }^{24}$

Roach, barbel and dace are fresh-water fish, normally regarded as intolerant of any significant degree of salinity. ${ }^{25}$ They would thus have been largely confined to the Thames upstream of the bridge and to the freshwater sections of the Thames tributaries. The fact that roach and dace fry were to be found down-river of London Bridge in 1386 is suggestive of high freshwater flow at that time, penetrating beyond the structure's damming effect, which seems to be supported by evidence for notably wet weather in both 1385 and $1386 .{ }^{26}$ Gudgeon is also a fresh-water species, common in the middle reaches of rivers, and like roach is of little commercial value today. To fishermen of earlier periods, however, it was valued and compared to

18. Calendar of Letter-Books Preserved among the Archives of the Corporation of the City of London at the Guildhall. Book A, ed. Reginald R. Sharpe. London: J. E. Francis, 1899: 186-188.

19. Calendar of Letter-Books Preserved among the Archives of the Corporation of the City of London at the Guildhall. Book D, ed. Reginald R. Sharpe. London: J. E. Francis, 1902: 198-199.

20. Calendar of Letter-Books Preserved among the Archives of the Corporation of the City of London at the Guildhall. Book H, ed. Reginald R. Sharpe. London: J. E. Francis, 1907: 279; Calendar of select pleas...: 116-119.

21. Serjeantson, Dale; Woolgar, Christopher M. "Fish consumption in Medieval England", Food in Medieval England: Diet and Nutrition, Christopher M. Woolgar, Dale Serjeantson, Tony Waldron, eds. Oxford: Oxford University Press, 2006: 126.

22. "Henry V: May 1421", Parliament Rolls of Medieval England, ed. Chris Given-Wilson, Paul Brand, Seymour Phillips, Mark Ormrod, Geoffrey Martin, Anne Curry, Rosemary Horrox. Woodbrige: Boydell, 2005. Available in British History Online. Institute of Historical Research and the History of Parliament Trust. 30 April 2019 <http://www.british-history.ac.uk/no-series/parliament-rolls-medieval/may-1421>. 23. "Henry VII: January 1489", Parliament Rolls of Medieval England, ed. Chris Given-Wilson, Paul Brand, Seymour Phillips, Mark Ormrod, Geoffrey Martin, Anne Curry, Rosemary Horrox. Woodbrige: Boydell, 2005. Available in British History Online. Institute of Historical Research and the History of Parliament Trust. 30 April 2019 <http://www.british-history.ac.uk/no-series/parliament-rolls-medieval/january-1489>.

24. Wright, Laura. Sources...: 85.

25. Wheeler, Alwyne. Tidal Thames...: 66-67, 110-111; Wheeler, Alwyne. "The origin and distribution...": 2 .

26. Kington, John. Climate and Weather. London: Collins, 2010: 231. 


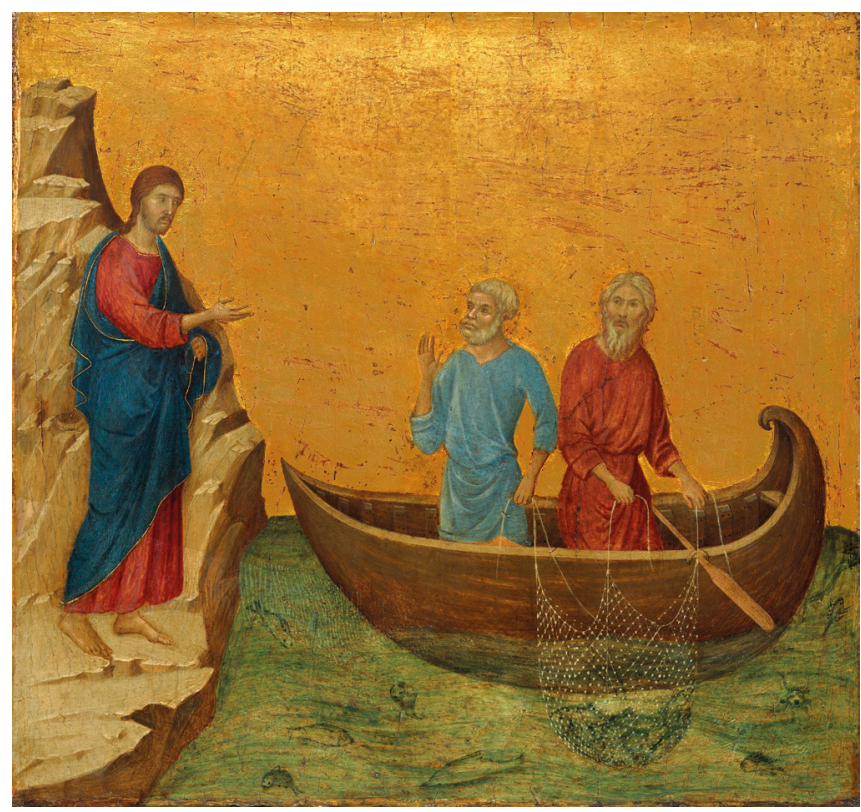

Illustration 3. Duccio, di Buoninsegna, D. 1319: The Calling of the Apostles Peter and Andrew (from the Maestà), c. 1308-1311. Thames fishermen were named "Peters" after the apostle. “Christ Calling the Apostles Peter and Andrew". Art in the Christian TRAdition. 26 January 2007. Vanderbilt Divinity Library. 16 MAY $2019<$ HTTP://DIGLIB.LIBRARY.VANDERBILT.EDU/ACT-IMAGELINK. PL?RC $=49261>$.

smelt both in its behaviour and perhaps in its taste -an $18^{\text {th }}$ century writer claimed that "when in perfection he deserves the name of the river-smelt." 27

In the outer estuary, beyond the area over which London claimed and attempted to exercise jurisdiction, more marine species were encountered. A court case from 1377 dealt with the alleged theft of fish and shellfish from a fishery (perhaps a fishweir) at Wakering, just to the west of Foulness Island, namely mullets, "merlyngs" (whiting) and "pectines" (probably scallops), together with salmon, oysters and mussels. ${ }^{28}$ Whiting caught in the Thames and brought to London by boat are

27. Grifftiths, Roger; Binnell, Robert. A Description of the River Thames $\theta$ c. with the City of London's Jurisdiction and Conservancy Thereof. London: Longman, 1758: 202.

28. TNA. CP40/466. Accessed through Anglo-American Legal Tradition. Documents from Medieval and Early Modern England from the National Archives in London. The O'Quinn Law Library of the University of Houston Law Center. 21 October 2018 <http://aalt.law.uh.edu/AALT4/E3/CP40no466/aCP40no466fronts/ IMG_0189.htm>. 
referred to in $1418 .^{29}$ Herring had long been caught around the estuary: in the late $11^{\text {th }}$ century Domesday Book recorded renders of herring at Luddenham in north Kent, as well as at London and Southwark. ${ }^{30}$ Sprats, which congregate in large numbers in estuaries, are mentioned in an Essex will of the mid-1 $6^{\text {th }}$ century, while the sprat boats which paid toll to the Constable of the Tower of London in the thirteenth and fourteenth centuries are likely to have been fishing the Thames mouth. ${ }^{31}$ Fish weirs and related structures on Foulness Island and in northern Kent caught large numbers of marine fish in the $19^{\text {th }}$ and early $20^{\text {th }}$ centuries, especially flat-fish (plaice, dab, sole and brill, in addition to flounder) together with juvenile herring and sprat, and it can be assumed that the numerous medieval weirs located in those areas did the same. ${ }^{32}$

\section{Fishers}

Fishermen and their families ${ }^{33}$ lived in settlements right around the Thames Estuary and tidal river. Despite London's importance as the premiere market for fish, relatively few of them appear to have lived in the city itself. Thus, in an admittedly rather small sample of forty Thames Estuary "fishers", drawn from indexed Court of Common Plea records from the early fifteenth century, only one was a Londoner. ${ }^{34}$ There were, however, notable concentrations of fishers in small towns and villages lying beside the Thames to the east of the capital. Offenders against London regulations regarding nets, weirs and fishing seasons to the east of London Bridge came overwhelmingly from a stretch of the Thames running from Greenwich, Stepney and the Isle of Dogs eastwards to Erith (see location on Illustration 1). On the north (Essex) bank, the largest numbers of fishermen falling foul of the Londoners' rules lived in Barking, East and West Ham and Rainham, while on the

29. Memorials of London ...: 667.

30. Darby, Henry C. Domesday England. Cambridge: Cambridge University Press, 1977: 285-286.

31. Emmison, Frederick G. Elizabethan Life: Home Work $\theta$ Land. Chelmsford: Essex County Council, 1976:

70; Kowaleski, Maryanne. "The early documentary evidence...": 28.

32. Smith, J.R. Foulness. A History of an Essex Island Parish. Chelmsford: Essex County Council, 1970: 14; Crump, Bob; Wallis, Steve. "Kiddles and the Foulness Fishing Industry", Essex Journal, 27/2 (1992): 3842. Benton, Philip. The History of Rochford Hundred. Rochford: Harrington, 1867: 185. Rays, bass, mullet, garfish, gurnard, shad and cuttlefish are also recorded as caught in these structures in modern times.

33. Women and children played an active role in many shore-based activities related to the processing and marketing of fish in most medieval fishing communities. Kowaleski, Maryanne. "Peasants and the sea in medieval England", Peasants and Lords in the Medieval English Economy: Essays in Honour of Bruce Campbell, Maryanne Kowaleski, John Langdon, Phillipp R. Schofield, eds. Turnhout: Brepols, 2015 : $353-$ 376.

34. Sample compiled from online indices for Court of Common Pleas plea rolls for Easter Term 1418, Michaelmas Term 1425, Hilary Term 1427, Easter Term 1430, Easter Term 1432, and Hilary Term 1434. Anglo-American Legal Tradition. Documents from Medieval and Early Modern England from the National Archives in London. The O'Quinn Law Library of the University of Houston Law Center. 12 October 2018<http:// aalt.law.uh.edu/Indices/CP40Indices/CP40_Indices.html>. 
south (Kent) bank, Erith appears preeminent, with significant numbers also living in Plumstead, Greenwich, Lesnes and Woolwich. ${ }^{35}$ How many fishers were active at any one time is impossible to gauge, but references to their periodic conflicts with officers of the City of London indicate that they were both numerous and formidable. Thus in 1407 a mob alleged to number 2,000 men from Woolwich, Erith, Barking and neighbouring places pursued and assaulted a City officer on the river, and seized back nets that he had confiscated for examination. ${ }^{36}$ The number was likely exaggerated, and not all of those involved may have been fishermen, but the impression of this being a very numerous group seems highly plausible.

Fishermen active along this stretch of the inner estuary were sometimes termed peters or petermen, taking their name from St Peter who, according to the New Testament, was a fisherman in Bethsaida when called into the service of Jesus (see illustration 3). In a 1390 mayoral proclamation peters "who bring fish from the Thames into the city to sell" were distinguished from ripiers, who bring fish from the sea. The ripiers worked principally out of Rye and neighbouring ports on the Channel coast, carrying fresh plaice and other fish to the city by packhorse. ${ }^{37}$ The striking recent discovery of a skeleton preserved in Thames mud at Bermondsey, on the south bank of the river just to the east of the city, may perhaps give us a physical encounter with a peterman from the close of the middle ages. The skeleton was wearing thigh-high leather boots, with reinforced soles and stuffed with an unidentified material - possibly moss - designed to make them warmer, and stitched with waxed thread. These look like waders, and strongly suggest that the owner was a fisherman or other riverside worker. The style of the boots suggests a date of c. 1500. The physical condition of the skeleton indicates a life of hard labour, with clear evidence of osteoarthritis, while the teeth have deep grooves indicative of their use in a repetitive action, such as holding a rope, as a fisherman might. ${ }^{38}$

A further concentration of fishing activity centred on Gravesend, where the tidal river opens out to form the outer Estuary, and around the marshes of the Hoo peninsula in Kent and Canvey Island in Essex. ${ }^{39}$ Tantalising archaeological evidence suggests that there may have been a significant medieval fish-processing centre at Leigh Beck at the eastern tip of Canvey Island: survey work during the 1970s and 1980s uncovered large quantities of bones from a wide variety of species, including

35. Calendar of Letter-Books...; Memorials of London...

36. Calendar of Letter-Books Preserved among the Archives of the Corporation of the City of London at the Guildhall, Book I, ed. Reginald R. Sharpe. London: J. E. Francis, 1909: 58-59.

37. Galloway, James A. "Ripiers and the Supply of Fresh Sea-fish to Later Medieval London." Academia. 12 May 2007 <https://www.academia.edu/12331505/Ripiers_and_the_Supply_of_Fresh_Sea-fish_ to_Later_Medieval_London>. Unpublished seminar paper, delivered to meeting of the Diet Group, University of Oxford.

38. Mola Headland Archaeology. "The medieval mystery of the booted man in the mud". Mola Headland Infrastructure. 1 April $2019<$ https://molaheadland.com/the-medieval-mystery-of-the-booted-man-inthe-mud>.

39. Wright, Laura. "Medieval Latin, Anglo-Norman and Middle English in a civic London text: an inquisition of the River Thames, 1421", De Mot en Mot: Aspects of Medieval Linguistics, David A. Trotter, Stewart Gregory, eds. Cardiff: University of Wales Press, 1997: 248-251. 
whiting, cod, haddock, herring, horse-mackerel and flat-fish. ${ }^{40}$ The village of Fobbing to the west of Canvey formed a notable focus of broader maritime activity, with 50 mariners listed among a taxpaying population of just 225 in $1372 .{ }^{41}$ Men from Cliffe on the Hoo peninsula and from Strood and Rochester at the mouth of the River Medway were active in fishing the marshes there and the tidal channels which bisect them. ${ }^{42}$ Further east again, a cluster of fisher residences is evident in Rochford Hundred in south-east Essex. ${ }^{43}$ Here access was possible both to the open waters of the outer estuary, and

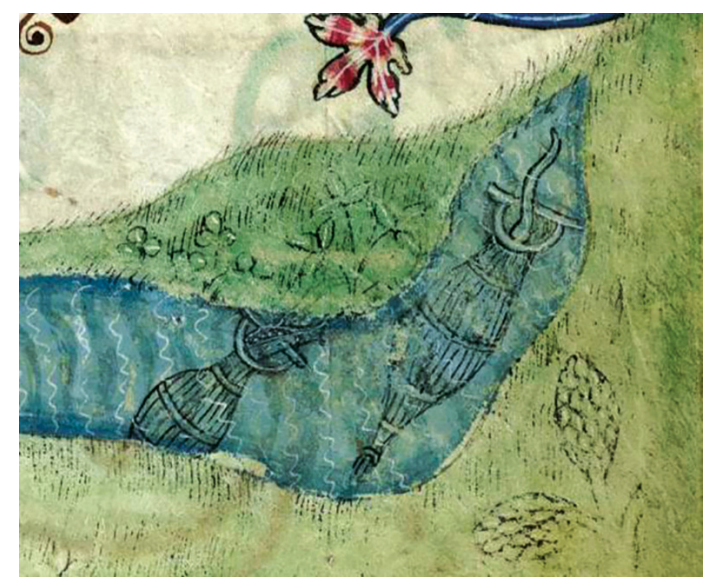

ILLUSTRATION 4. WiCKER FISH-TRAPS PLACED IN A MILLRACE: Detall From $14^{\text {TH }}$ CENTURy Luttrell Psalter. British Library, Add MS 42130. Provided by the author (C) Creative Commons Attribution Non Commercial Licence. to the marshes on and adjoining Foulness Island. On the shores and channels of north-eastern Kent, fishermen were active around the Isle of Sheppey, at Milton, in the busy port of Faversham, at Whitstable and eastwards towards Thanet. In 1566 seventeen out of twenty Kentish ports and landing places surveyed listed fishing as the main employment of their shipping. ${ }^{44}$

The prominence of particular places or stretches of shoreline in the documentary record points to some of the most commercially significant centres of fishing activity; it seems clear, however, that some level of fishing activity, whether for subsistence or as a minor commercial adjunct to other activities, was to be found virtually everywhere around the estuary and the tidal river in the later middle ages. Thus 37 out of 197 testators from Reculver and neighbouring Herne in north-eastern Kent bequeathed fishing apparatus, principally weirs, in wills dating from before 1558. It appears that for virtually all of the individuals in this sample fishing was a secondary

40. Wilkinson, Tony J.; Murphy, Peter J., dirs. The Archaeology of the Essex Coast, volume 1: the Hullbridge Survey. Chelmsford: Essex County Council, 1995: 191-192.

41. Kowaleski, Maryanne. "Peasants and the sea...": 358.

42. Liber Albus: the White Book of the City of London, ed. Henry T. Riley. London: Richard Griffin, 1861: 429-430.

43. Anglo-American Legal Tradition... See note 34 above.

44. Draper, Gillian. "Timber and iron: natural resources for the late medieval shipbuilding industry in Kent", Later Medieval Kent, 1220-1540, Sheila Sweetinburgh, ed. Woodbridge: Boydell-Kent County Council, 2010: 55-78; Wilkinson, Paul. The Historical Development of the Port of Faversham, Kent 1580-1780. Oxford: Archaeopress, 2006: 73. 
occupation -or, at least, was not their sole occupation- as they all also owned or held land or an agricultural interest of some kind. ${ }^{45}$ An inquisition into the lands and possessions of William Piryman of Stanford le Hope in Essex, held in 1420, gives us a valuable insight into the activities of one part-time fisherman. ${ }^{46}$ Piryman owed $£ 30$ to three London citizen fishmongers and, when he defaulted on repayment, his possessions were seized by the Sheriff of Essex. These included three kiddle nets, which would have been used in a typical Thames fishing-weir, and an "old boat". In addition, however, Piryman held 23 acres of arable land, some of which were sown with wheat, barley and rye, had rights in common pasture in the Thamesside marshes, and possessed a cow, a "weak horse" and some poultry. Thus, his fishing was supplementary to his farming activities. The fact that Piryman's creditors were London fishmongers suggests involvement in commercial supply of fish to the capital, but this cannot be certain.

\section{Fishing techniques and equipment}

The equipment required to participate in fishing the tidal Thames and the estuary varied widely, from a simple line and hook, or small wicker-work trap, through to medium-sized boats equipped with substantial nets and the major post and net or post and wickerwork weirs and kiddles. Line-fishing is evidenced by the finding of quite large numbers of barbed fish-hooks in medieval contexts in London, although at times regulations were passed forbidding fishing with an angle. ${ }^{47}$ The variation in size of the hooks found, which range from $32 \mathrm{~mm}$ to $75 \mathrm{~mm}$ in length, reflects the variety of fish which might be caught in the Thames. ${ }^{48}$ Shellfish might be gathered by hand in the intertidal zone, although the value of oyster and mussel grounds leased in the fourteenth century certainly reflects larger-scale dredging activities. ${ }^{49}$ Eels could be caught by multiple-pronged spears, late medieval examples of which have been found on the Thames foreshore at London. ${ }^{50}$

45. Dulley, A. J. F. "Four Kent Towns at the End of the Middle Ages", Essays in Kentish History, Margaret Roake, John Whyman, eds. London: Frank Cass, 1973: 69.

46. TNA. C 131/60/15.

47. Steane, John M.; Foreman, Martin. "The archaeology of medieval fishing tackle", Waterfront Archaeology: Proceedings of the third international conference on waterfront archaeology held at Bristol 23-26 September 1988, George L. Good, Robert H. Jones, Michael W. Ponsford, eds. London: Council for British Archaeology, 1991: 146-147; Wright, Laura. Sources...: 54.

48. The relatively large hook size overall may also reflect a largely marine/estuarine catch. Hoffmann, Richard C. "Medieval fishing", Working with Water in Medieval Europe: Technology and Resource-Use, Paolo Squatriti ed. Leiden-Boston-Koln: Brill, 2000: 349-350.

49. At the manor of Milton on the Essex shore of the outer estuary mussel grounds were rented out for $£ 2$ per annum c. 1300, rising to $£ 3.15 \mathrm{~s}$ in the later fourteenth century. CCA. DCc/Middleton 15-70.

50. Steane, John M.; Foreman, Martin. "The archaeology of medieval fishing...": 139-140; “Eel spear". Museum of London. 21 January $2019<$ https://collections.museumoflondon.org.uk/online/ object/29609.html >. 
Small fish-traps were probably very common, although their presence in the documentary record is relatively slight, doubtless because their perceived impact on fish-stocks was minimal compared to larger structures, while they would not normally have posed any threat to navigation. Berds or berdpots appear to have been wicker baskets with a narrow, funnelled opening, used to trap fish and perhaps crustaceans. ${ }^{51}$ Burrocks were another type of trap, perhaps larger, and twenty-two of them were found to have been placed on the downstream side of London Bridge in 1385-1386, where they had trapped fry of roach, flounder, lampern and dace. A wilchon was a further type of trap, probably also of wickerwork, recorded as in use in the vicinity of the Bridge. Petermen and others were accused on several occasions in the late $15^{\text {th }}$ and early $16^{\text {th }}$ centuries of causing nuisance and damage to the starlings, the boat-shaped foundation structures around the piers of the Bridge, by laying "nettes, wylchons and other engynes... under and nygh to the same brydge".$^{52}$ The Wardens of the Bridge petitioned in 1481 that fishing be prohibited within 20 fathoms of any starling. Other traps, known as wases and willys, appear to have been devised for placing on a weir, perhaps for catching eels; other terms encountered include a cripple and a lam, which seems to have been a small trap woven from reeds. ${ }^{53}$ These traps probably resembled those illustrated in the $14^{\text {th }}$ century Luttrell Psalter (see illustration 4).

Despite their relatively flimsy and perishable nature, archaeological finds of small late-medieval fish-traps have been made. Numerous examples of wickerwork have been observed at sites along the Thames foreshore, within the intertidal zone, and in 2010 samples were taken from a panel of basket work (c. $1.2 \times 0.7 \mathrm{~m}$ ) woven from reeds and believed to form part of a portable fish or eel trap. Radiocarbon dating of the sample, which was located at Millwall on the Isle of Dogs to the east of London, returned a date of AD 1415-1450. ${ }^{54}$ This trap may have resembled the more complete specimen, dating from c. 1500, which was recovered from the moat of the Tower of London. Inside the latter were found weights and 177 bone fragments, from eel, flounder, tench and chub. ${ }^{55}$

Nets were employed in numerous ways to fish the tidal Thames and the Estuary, being drawn from boats, or by hand, or attached to fixed posts and weirs. In the documentary sources, however, it is often not clear what methods were being used, as reference may be made only to the forfeit of nets employed in an illegal way - commonly at the wrong season, or with too narrow a mesh- but without

51. Wright, Laura. Sources...: 55-56. Similar types of trap were in use across medieval Europe. Hoffman, Richard C. "Medieval fishing...": 352-354. A fine selection of traps and other traditional fishing equipment in use down to modern times can be seen in the Aquamuseu do Rio Minho, Vila Nova de Cerveira, Portugal.

52. Calendar of Letter-Books Preserved among the Archives of the Corporation of the City of London at the Guildhall, Book L, ed. Reginald R. Sharpe. London: J. E. Francis, 1912: 180-181; Wright, Laura. Sources...: 81-82.

53. Wright, Laura. Sources...: 60, 67-68, 78-79, 83.

54. Cohen, Natalie; Stevens, Nick. “Medieval fishing on the Isle of Dogs”. London Archaeologist, 13 (2011): 231.

55. Keevill, Graham. The Tower of London Moat: Archaeological Investigations 1995-1999. Oxford: Oxford Archaeology, 2004: 124-131. 
details of their usage. In the case of the smelt fishery, perhaps the most important commercial fishery of the inner estuary, it seems apparent that the fish were taken by nets drawn by boat: in 1386 a jury of fishermen testified that smelt nets, which had a narrow mesh of one inch, were to be used in late winter/early spring "without dragging these nets anywhere to land near London, but fishing only in the middle of the stream". The net used for smelt and gudgeon is also described as a draghnet. ${ }^{56}$ The important smelt fishery of later centuries certainly was based upon fishing with nets from boats. ${ }^{57}$ The narrow mesh net was only to be used between $2^{\text {nd }}$ February and $25^{\text {th }}$ March, with a mesh of a minimum of 2 inches to be used during the remainder of the year. A possible exception, claimed in 1386 by a group of fishermen jurors from upstream of the Bridge, was that in years of very mild conditions, "when the scoue [school or shoal] of smelt and gudgeons drew closer to the land," it was judged permissible to use the narrow gauge net for 2 week prior to the $2^{\text {nd }}$ February. ${ }^{58}$

Sprats were caught by boats fishing with nets in the estuary, between the Tower of London and the open sea. The Constable of the Tower levied toll on boats occupied in this fishery, which were known as stalebotes. Both London and non-London boats were involved: in 1285-1286 the Constable levied 40 shillings from six London boats, which each paid 6s $8 \mathrm{~d}$ and 48 shillings from six "foreign" boats paying 8 shillings each..$^{59}$ Non-citizens carrying sprats for sale in London are also recorded as liable to render a toll of one "tandel" from each boatload. ${ }^{60}$ By the sixteenth century some of the boats fishing the tidal Thames seem to have been quite large. In 1536 we hear of "dreye shyppys", each of which employed eight or nine men, "who sell the marketable fish and live upon the small". The number of these ships working the Thames upstream of the Bridge was said to have increased from three to six, and below the Bridge from four to ten or twelve. These ships were said to 'shoot their nets' every day, to the great detriment of fish stocks; a petition to the King's Council requested that they be allowed to come no further up the Thames than the cross at Ratcliffe (between the Tower and the Isle of Dogs). ${ }^{61}$

Other nets were operated from the shore, as appears to have been the case in the salmon fishery at Shene upriver of the Bridge. Expenditure of the fishery there included money laid out on "harnet" and "shotnet", and on lengths of landing-rope for pulling the nets to land. ${ }^{62} \mathrm{~A}$ twelfth-century inquest into liberties exercised over the Thames heard that seine nets, employing floats at the top and weights at the

\footnotetext{
56. Calendar of select pleas...: 117

57. Wheeler, Alwyne. Tidal Thames...: 48-49.

58. Calendar of select pleas...: 118

59. Kowaleski, Maryanne. "The early documentary evidence...": 28. TNA. E101/4/10.

60. Wright, Laura. Sources...: 113.

61. Letters and Papers, Foreign and Domestic of the Reign of Henry VIII, ed. John S. Brewer. London: His Majesty's Stationery Office, 1864-1920, 21 vols; Letters and Papers, Foreign and Domestic of the Reign of Henry VIII, ed. John S. Brewer. London: His Majesty's Stationery Office, 1932: Addenda, 1364-1365 (docs. No. 1048-1049).
}

62. Hoffman, Richard C. “Medieval fishing...": 361. 


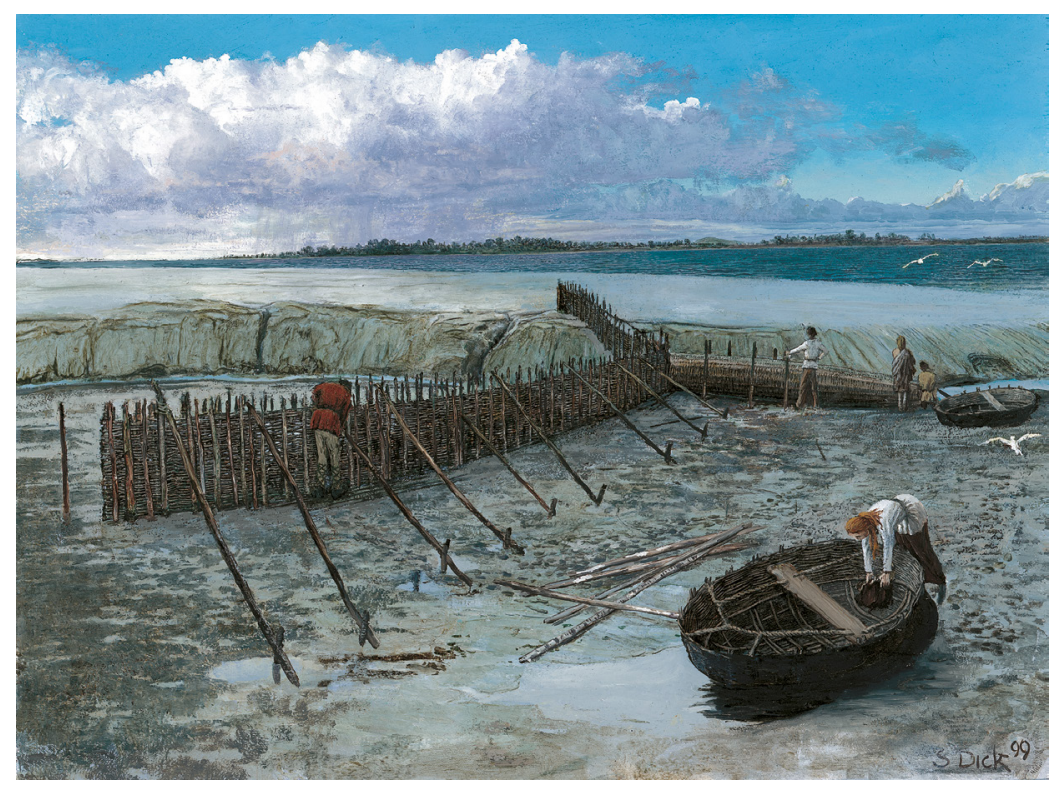

Illustration 5. Reconstruction of a medieval fish weir, by Simon Dick. This EXAMPLE FROM IRELAND IS LIKELY TO HAVE CLOSELY RESEMBLED TYPES IN USE IN THE Thames Estuary. Reproduced courtesy of University College Dublin, School of Archaeology.

bottom and being cast from the shore, were in use within the Liberty of Baynards Castle, one of the strongholds which controlled access to the city from the west. A number of such nets were said to have been forcibly confiscated and burnt in the house of the keeper of the waters..$^{63}$ Other nets referred to between the thirteenth and sixteenth centuries include "blees" or "bleenets", which may equate to "peternets", i.e. nets employed by petermen; "casting nets"' alias "pursenets", which were probably small nets that were thrown from the shore or from a boat, rather than anything resembling a modern purse seine net, ${ }^{64}$ "dredges" and "draynets", nets which were dragged through the water and contained a cod or bag, as did "codnets"; "flownets", perhaps a type of gillnet; "forstates"; and "shovenets", apparently a net with a rigid frame which was worked by being pushed along the riverbed. ${ }^{65}$

Dredging was commonly used for harvesting shellfish, including oysters all around the Essex coast. A number of "draggers" or dredgers of oysters are identified in the

63. Summerson, Henry. "The 1215 Magna Carta: Clause 33, Academic commentary". The Magna Carta Project. 9 November 2018 <http://magnacarta.cmp.uea.ac.uk/read/magna_carta_1215/ Clause_33?com=aca>.

64. A 1388 ordinance prohibited the use of "pursnets". Riley equates these to the "codnets" used for centuries on the Thames, containing a cod or purse weighted with a stone: Memorials of London: 508.

65. Wright, Laura. Sources...: 56, 58-62, 69, 71-72, 75. 
fragmentary 1381 poll-tax returns for Tollesbury, at the mouth of the Blackwater. ${ }^{66}$ South-east Essex was also a major source of mussels. When, in 1365, the bailiff of Queenhithe in London was accused of using an inconsistent variety of measures for mussels brought in by boat for sale, at least four of the seven complainants were men from Prittlewell. ${ }^{67}$ In 1509 the draggings of mussels in Tilbury Hope, the stretch of the tidal Thames east of Gravesend, was granted to Katherine of Aragon. ${ }^{68}$ The north Kent oyster grounds, which like those of Essex, were famed in later centuries, were also being commercially exploited in the later medieval period, especially around Faversham, Queenborough and Whitstable. ${ }^{69}$ Technological developments in the later medieval period included the development of a trawling net known as the wondyrchoun, described in 1377 as "made in the manner of a drag for oysters", but "immeasurably long". ${ }^{70}$ These small-mesh nets were reported to be having a major impact on the Essex coast, in particular the estuaries of the Colne and Blackwater, where they were damaging spawning grounds and oyster beds. ${ }^{71}$ It is likely that they were also employed around the mouth of the Thames Estuary.

Much of the fishing carried out around the Thames estuary and tidal river employed fixed structures, much larger than the small traps discussed earlier and generally referred to as weirs (gurges in Latin) or frequently in the Thames area as kiddles (kiddeli). ${ }^{72}$ Such devices were commonly v-shaped, and used "arms" constructed of wickerwork or netting to guide or channel fish towards a basket or net at their apex. The archaeological evidence for these structures is heavily biased towards the Anglo-Saxon (early medieval) period. A number of weirs, constructed using timber posts and wickerwork panels and dating between the fifth and ninth centuries $\mathrm{AD}$, have been identified in the Thames upriver of London, Some of these may have been v-shaped, others may have functioned by linking "eyots" or small islands within the braided channel of the river. ${ }^{73}$ From the same early medieval period, a number of very massive fish weirs are known from parts of the Essex coast

\section{TNA. PRO E179/107/64.}

67. Calendar of select pleas and memoranda of the city of London AD 1364-1381, ed. Arthur H. Thomas. Cambridge: Cambridge University Press: 29-30.

68. Letters and Papers, Foreign and Domestic of the Reign of Henry VIII, ed. John S. Brewer. London: His Majesty's Stationery Office, 1864: I, 21 (doc. No. 155).

69. Goodsall, Robert H. “Oyster fisheries on the North Kent Coast”. Archaeologia Cantiana, 80 (1965): $118-151$.

70. “Edward III: January 1377". Parliament Rolls of Medieval England, ed. Chris Given-Wilson, Paul Brand, Seymour Phillips, Mark Ormrod, Geoffrey Martin, Anne Curry, Rosemary Horrox. Woodbrige: Boydell, 2005. Available in British History Online. Institute of Historical Research and the History of Parliament Trust. 4 May 2019 <http://www.british-history.ac.uk/no-series/parliament-rolls-medieval/ january-1377>; Hoffman, Richard C. "Medieval fishing...": 364

71. Bailey, Mark. "Coastal fishing off south-east Suffolk in the century after the Black Death". Proceedings of the Suffolk Institute for Archaeology, $37 / 2$ (1990): 110.

72. I have adopted the spelling "kiddle", as it is the form most generally in use down to modern times. Laura Wright prefers the earlier form "kidel".

73. Cohen, Nathalie. "Early Anglo-Saxon fish traps on the River Thames", Studies in early Anglo-Saxon Art and Archaeology: Papers in Honour of Martin G. Welch, Stuart Brooks, Sue Harrington, eds. Oxford: Archaeopress, 2011: 131-138. 
adjoining the Thames Estuary. Typically dating to c. 650-800 AD, these weirs were v- or l-shaped structures built of oak, alder, birch or willow posts supporting fences or 'arms' of between $100 \mathrm{~m}$ and $300 \mathrm{~m}$ in length. At their apex were baskets of hazel where the fish were trapped. Some of these weirs seem to have been associated with early ecclesiastical and monastic sites. Some provide evidence of processing at the point of capture, with the Sales Point weir on the Blackwater Estuary having a thick associated deposit of fish bones, indicating that cod and bass were being gutted and filleted on the mud-flats. ${ }^{74}$

In contrast to this impressive early medieval evidence, the later middle ages have produced little clear-cut archaeological evidence for the use of fish-weirs in the Thames area. ${ }^{75}$ The documentary record, on the other hand, is exceedingly rich in references to fishing weirs in use between the 12th and 16th centuries. They were commonly adjuncts to landed property bordering the Thames and its estuary, owned by lay and ecclesiastical lords or the crown, and leased out to tenants who worked them, harvesting the catch for consumption and for sale (see illustration 5). An evidently large weir at Gray's Thurrock in Essex was rented out for $£ 2$ 13s $4 \mathrm{~d}$. in the accounting year 1290-1291, while a manorial account for Foulness shows the lord receiving nearly $£ 10$ for the fishery there over the period between Easter and Michaelmas 1424, including rents from the strikingly large number of 75 weirs and kiddles. ${ }^{76}$ The Abbess of Barking and the Abbott of Stratford were leasing out places for weirs in the flooded West Marsh of Barking in the later fourteenth century. ${ }^{77}$ London sources, moreover, demonstrate something close to an obsession with these structures, and leave no room for doubt that they were extremely numerous in the Thames area during the later middle ages. Early charters granted to the city included the right to suppress weirs in the Thames and the Medway, and the Magna Carta of 1215 included a provision that "all kiddles... be utterly put down in the Thames and Medway and throughout England excepting the sea-coast."78 Numerous royal and civic ordinances and statutes thereafter attempted to control, restrict or totally remove weirs or kiddles, and the Londoners actively attempted to enforce them. ${ }^{79}$

74. Strachan, David. "Inter-tidal stationary fishing structures in Essex: some C14 dates". Essex Archaeology and History, 29 (1998): 274-282.

75. The Historic Environment Record for Kent includes references to the remains of numerous weirs or possible weirs along the estuary shores, especially in the Whitstable and Graveney areas, and around the mouth of the Medway, but they are almost all undated. "Resource Summary Results". Heritage Gateway. Kent Historic Environment Record. 29 April 2019 <https://www.heritagegateway.org.uk/Gateway/ Results_Application.aspx?resourceID=1005>.

76. ERO. D/DU 1364/1; Smith, John R. Foulness...: 13-14.

77. Galloway, James A. “Tempests of weather...": 77-78.

78. Summerson, Henry. "The 1215 Magna carta..." The Anglo-Norman word "kiddle" is found in Medieval Latin contexts in numerous texts from 1180 onwards: sometimes it seems to be used simply as a synonym for "weir", more commonly it appears to denote a specific type of v-shaped weir, constructed with walls of netting rather than wicker panels. Wright, Laura. Sources...: 66-67; Howlett, David R., ed. Dictionary of Medieval Latin from British Sources. Oxford: Oxford University Press, 1997: fascicule V, 1527.

79. Barron, Caroline M. The Government of London and its relations with the Crown, 1400-1450. London: University of London (PhD Dissertation), 1970: 357-365; Bond, James. "Monastic fisheries", Medieval 
In 1237 the owners of thirty-seven kiddles around the Medway mouth and the Hoo peninsula, including men from Rochester, Strood and Cliffe, were brought to London, and their nets destroyed. ${ }^{80}$ Fourteenth-century seizure of kiddle nets or destruction of weirs is recorded as having taken place at Barking, Woolwich, Erith, Plumstead, Lesnes and other locations around the tidal river east of London Bridge. Kiddles, weirs and other "engines" were blamed for "the destruction of fry and salmon"' and for "disturbing the passage of ships and boats and destroying the fish." ${ }^{81}$ Thus, Londoners' concerns extended both to the navigability of the Thames and its estuary and to the conservation of fish-stocks which were seen as being menaced by the numerous weirs and kiddles. Indeed, the Mayor and Aldermen were concerned in 1386 that the Thames fish were "so destroyed that hardly a seasonable fish could be found": the blame was placed, again, upon weirs and nets of excessively small mesh, and upon another fixed device known as the trink or trink-net. ${ }^{82}$

The earliest references to trinks, from c.1300, imply they were merely a type of net, of minimum $1 \frac{112}{2}$ inch gauge, but by the later fourteenth century the term seems to denote a type of fishing device whereby a net was fixed in position, by attachment to a post or posts, or to an anchored boat, and used in the same way as a weir or kiddle to funnel fish into a catching area. In 1380 the Mayor and Aldermen of London ordained that "all trinks and other engines placed in the Thames for the destruction of fish" should be removed. ${ }^{83}$ In 1421 a petition to Parliament from the fishermen of the river Thames requested the removal of "nets called trinks, and other nets, weirs and traps situated and employed in the same river, made of such narrow mesh that a large part of the fry of salmon, trout, mullet, and other fish is, and has been, caught in the same and wasted, or given to pigs to eat." ${ }^{84}$ Two years later, a further petition included trinks, "accustomed to be continuously fastened and attached both night and day at certain times of the year to the large posts, boats and anchors which cross the river Thames and other rivers of the realm", alongside

Fish. Fisheries and Fishponds in England, Mick Aston, ed. Oxford: British Archaeological Reports, 1988: 86-89.

80. Liber Albus...: 429-430.

81. Calendar of Letter-Books Preserved among the Archives of the Corporation of the City of London at the Guildhall, Book E, ed. Reginald R. Sharpe. London: J. E. Francis, 1903: 115, 237-238; Calendar of select pleas...: 116117; "Richard II: November 1390", Parliament Rolls of Medieval England, ed. Chris Given-Wilson, Paul Brand, Seymour Phillips, Mark Ormrod, Geoffrey Martin, Anne Curry, Rosemary Horrox. Woodbrige: Boydell, 2005. Available in British History Online. Institute of Historical Research and the History of Parliament Trust. 4 May 2019 <http://www.british-history.ac.uk/no-series/parliament-rolls-medieval/ november-1390>.

82. Calendar of select pleas...: 116.

83. Calendar of Letter-Books Preserved among the Archives of the Corporation of the City of London at the Guildhall, Book H...: 143.

84. "Henry V: May 1421". Parliament Rolls of Medieval England, ed. Chris Given-Wilson, Paul Brand, Seymour Phillips, Mark Ormrod, Geoffrey Martin, Anne Curry, Rosemary Horrox. Woodbrige: Boydell, 2005. Available in British History Online. Institute of Historical Research and the History of Parliament Trust. 6 May 2019 <http://www.british-history.ac.uk/no-series/parliament-rolls-medieval/may-1421>. 


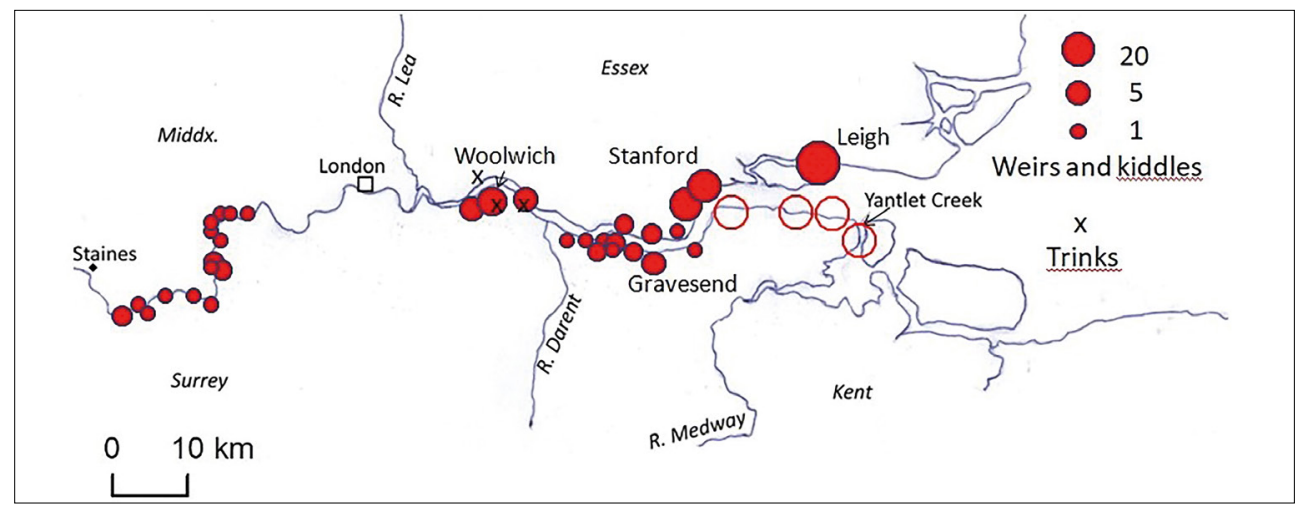

Illustration 6. Weirs and kiddles enumerated in the 1421 Survey. Provided by the author.

weirs and kiddles as dangers to navigation, as well as threats to fish stocks. ${ }^{85}$ In 1536 it was claimed that twenty-eight trinks stood between Blackwall and Northfleet where previously there had been ten. ${ }^{86}$

\section{The 1421 survey $^{87}$}

While these types of references in the documentary record suggest in a general way that the Thames fisheries were important to London, they are not quantifiable, but rather are episodic, relating to a lot of different dates, and to areas that had happened to attract the Londoners' attention at a particular time. More useful would be information on how many weirs, kiddles and similar devices were operating at any one time, and who owned or leased them. Luckily there is one source surviving which gives us an insight into this: a great survey of the stretch of the river and estuary over which the city claimed jurisdiction, drawn up in $1421 .^{88}$ Juries were empanelled at Brentford in Middlesex, Kingston in Surrey, Rainham in Essex and Gravesend in Kent to enquire into the 'destruction of fish' and obstructions to the passage of vessels, and other related transgressions. The return, which is highly

85. "Henry VI: October 1423". Parliament Rolls of Medieval England, ed. Chris Given-Wilson, Paul Brand, Seymour Phillips, Mark Ormrod, Geoffrey Martin, Anne Curry, Rosemary Horrox. Woodbrige: Boydell, 2005. Available in British History Online. Institute of Historical Research and the History of Parliament Trust. 6 May 2019 <http://www.british-history.ac.uk/no-series/parliament-rolls-medieval/october-1423>.

86. Letters and Papers...: Addenda 1, 364-365 (docs. No. 1048-1049).

87. A full transcript and translation of this survey is printed in Wright, Laura. "Medieval Latin...": 228251. Except where otherwise footnoted, the present section is wholly based upon this text.

88. It is clear from city records that other surveys of this type were attempted during the fifteenth century, but detailed returns do not appear to survive: Barron, Caroline M. "The Government of London...": 357 365 . 
detailed, suggests that the Thames fisheries fell into a number of zones, characterised by different types of fishing equipment and techniques ${ }^{89}$ and differences in the pattern of foundation and ownership of fixed fishing structures.

The survey begins with the part of the stretch of the Thames over which London claimed jurisdiction that lay upriver of the city, and hence was not estuarine in the sense used in this paper. Nonetheless, it is worth briefly reviewing the survey text for this part of the river, as it displays significant contrasts with the estuary proper. Upriver of London, and probably largely beyond the reach of tidal influence, twenty large fishing structures were identified, together with many of the smaller traps known as wases. Most of the large structures were simply called weirs - but at West Brentford, Isleworth, Petersham and near Shepperton they were described as "routes". From their descriptions, these latter seem to have been structures extending out into the river at right angles to the bank, for between 100 and 300 feet, and hung with wickerwork baskets and traps or nets. The jurors were asked how long each structure had been in place; in five cases, they were said to predate the coronation of Edward I (1274), nine were of unknown age or had been in place longer than the jurors could recall, one had been built at some point since 1274, one was newly raised and the remaining five were said to have been constructed within the previous 14 years.

Strikingly, the old weirs, and those of indeterminate age, had mostly been founded by religious houses, including Westminster Abbey, Merton Priory and several London establishments: St John of Jerusalem, Clerkenwell, the Hospital of St Mary without Bishopsgate, and the Bishop of London. The newly established Syon Abbey at Sheen had been endowed with old-established weirs at Isleworth and Ham. These old and mostly church-owned weirs (one was said to be owned by a lay lord and one weir by the crown) were now all rented out to local lay people, many of them described as fishermen. They were said to have been constructed well, with a 3 inches mesh, but the recent renters were alleged to have been responsible for over-extending them, and for fitting baskets or nets of overly small mesh, resulting in the trapping and destruction of fry, which the jurors claimed were being fed to pigs. It thus seems likely that many of the weirs upriver of London were long-established and had been set up at an early date to supply religious and other households with eels and river fish: the jurors made particular mention of salmon and lamprey among the fish being harmed by the weirs, and these fish were of course commonly consumed in great households. ${ }^{90}$ Some of the fish being trapped in 1421 were probably contributing to London's food supply, but now via the market rather than through direct provisioning.

Although there is nothing to suggest that the 1421 survey is incomplete, it records no weirs between Grove, just downstream of Kew, and the vicinity of Woolwich, about $16 \mathrm{~km}$ down-river from London (see illustration 6). This may perhaps indicate that the Londoners had succeeded in suppressing large weirs

89. Always with the proviso that some of the differences may reflect differences in local terminology. 90. Serjeantson, Dale; Woolgar, Christopher M. "Fish consumption...": 125-126. 
or kiddles in the immediate vicinity of the city, but not over the whole extent of their claimed jurisdiction. It is, however, worth noting that the survey describes fixed fishing devices "in the River Thames". The 1386 inquisition into the shortage of fish had made it clear that much damage was being done by trinks, weirs and "hebbyngnets" (nets spread between two poles to trap fish at the mouth of a creek or inlet as the tide goes out), placed in "fleets" (inlets or creek mouths) and "shores" (shores or sea-marshes), ${ }^{91}$ and in the great breach in the river wall at Barking. ${ }^{92}$ The breach at Barking had been caused by storm surges in the 1370s, and had already been the cause of great concern to the London authorities. ${ }^{93}$ Thus, it is possible that while weirs and kiddles had been removed from this stretch of the Thames channel, they were still operating in tributary inlets, creeks and tidal (including recently flooded) marshes. It is also apparent that small traps, which did not pose a threat to navigation, were common in the waters close to London where no large weirs are recorded.

In the part of the inner estuary from Woolwich eastwards the fixed fishing devices in 1421 were described either as weirs (sometimes qualified as great or small, or as foot weirs or pightweirs, the latter perhaps referencing the way they were pitched or fixed in position), or as kiddles. The further out towards the sea, the more commonly the devices were called kiddles. The existence of multiple weirs or kiddles at some locations is noteworthy: there were, for example, six pightweirs at Woolwich, twenty kiddles each at Mucking and Stanford-le-Hope and forty at Leigh, a parish which included the eastern extremity of Canvey Island. At some locations there were merely said to be "many" kiddles: on the map (see Illustration 6) these are represented as open circles equivalent in size to twenty elsewhere. In addition, the survey notes the use of trinks: six Barking fishermen were found to have trink nets of too fine a mesh, and it was noted that they should be "drawn just as other fishing nets are drawn", presumably implying that they were, in fact, being fixed to posts or other structures. A further seven fishermen from Woolwich and seventeen from Erith were found to have trinks which were too narrow and defective.

Clearly there was more shore-line out in the estuary on which to place fixed fishing structures than there was along the river in Middlesex and Surrey. The descriptions of the devices in Essex and Kent are less detailed, so it is difficult to know if they were comparable in size to those further west - some may have been smaller ("small weirs") — ${ }^{94}$ but overall it seems clear that the scale of fishing must have been greater. It also seems to have been more dynamic, in that the great

\footnotetext{
91. Definitions from Wright, Laura. Sources...: 64-65, 122-123. The use of the term "shore" for a drain or sewer, which would also make sense in this context, is not documented until 1598 .

92. Calendar of select pleas...: 116-117.

93. Galloway, James A. “Tempests of weather...": 72-79.

94. However, a weir built or rebuilt on the royal manor of Gravesend in 1373-4 was a substantial structure, using 27 elm posts and 7,900 rods of unspecified wickerwork. These materials cost $£ 2.5 \mathrm{~s} .4 \mathrm{~d}$., plus transport, and the labour of two men constructing the weir came to $53 \mathrm{~s} 4 \mathrm{~d}$, representing perhaps 70 or more days work by each man: TNA. E101/480/3/1.
} 
majority of the structures were said to have been constructed within six, ten or twenty years of the inquisition, while others were described as "newly raised" and a few were of unknown age. At several locations the jurors mention pales or posts from old or broken weirs, suggesting that the location of weirs shifted in response to changes in fish abundance or shoreline topography and perhaps also in response to punitive visits from the London authorities. The only functioning weirs reckoned by the jurors to be of significant age were a weir at Gravesend owned by the Abbey of St Mary Graces, London, and which was believed to have been erected before $1327,{ }^{95}$ and a large weir between Tilbury and Stanford of unknown origin but in the possession of one William Gatton in 1421 .

The great majority of the weirs and kiddles were said to be held, or to have been erected by fishermen from small towns including Ham — probably East Ham-, Erith and Gravesend. Men from Ham in Essex owned weirs on the Kent shore, and Gravesend men owned weirs and kiddles on the Essex shore. Some names occur more than once, implying a larger scale of operations: John Petygo of Gravesend owned a great weir near West Thurrock on the Essex shore as well as two more near Gravesend itself. He may be the same John Petygo who appears in a debt case in 1420 claiming $£ 5$ from a Chelmsford ostler or innkeeper, perhaps for the supply of fish. The aptly named John Haddock was co-owner of the 40 kiddles at Leigh. The Haddock family were tenants of the manor of Leigh, and from at least as early as 1327 had held land as well as a share of the common marsh there. ${ }^{96}$ The proximity of Leigh Beck on Canvey Island with its archaeological evidence suggestive of medieval fish-processing should be noted. ${ }^{97}$

It seems clear that much of this activity was commercially-oriented rather than representing either the direct provisioning of great households or subsistence fishing. The 1421 survey suggests that there were over 200 weirs and related large devices between Woolwich and the Medway mouth. There were clearly very many more uncounted on the seaward side, beyond the zone London aspired to control. As noted earlier, a manorial account from 1424 for the marshland island of Foulness, at the mouth of the estuary, shows the lord collecting rent on fiftyseven weirs and eighteen kiddles, while around one in six of the of will-making inhabitants of Herne and Reculver on the north Kent coast bequeathed weirs or shares in weirs in the late fifteenth and early sixteenth centuries. ${ }^{98}$ A similarly high degree of involvement is likely in many other estuarine communities. Moreover, it seems that the 1421 survey principally counted fishing devices within the channel of the river and along the banks of the estuary - outside sea-walls where they

\footnotetext{
95. Perhaps the weir rebuilt in 1373-1374; see note 94 above. St Mary Graces was a Cistercian house founded in 1350 by Edward III who before his death in 1377 made provision for various manors including Gravesend to be transferred to the abbey. This conveyance finally occurred in 1398. Barron, Caroline M.; Davies, Matthew, eds. The Religious Houses of London and Middlesex. London: University of London, 2007: 76-79.

96. Benton, Philip. The History of Rochford Hundred...: 317.

97. See note 40 above.
}

98. See notes 45 and 76 above. 
existed- and did not necessarily include those which had been established on the tidal creeks of saltmarshes, whether these were primary or secondary, floodingengendered marshes. In all, we must envisage many hundreds of weirs, kiddles and related structures operating around the tidal Thames and the Estuary at any one time.

The volume of fish caught by all these fixed fishing structures is impossible to estimate accurately, but clearly it must have been very considerable. The kiddles of Foulness were harvested by horse and cart and in more modern times and "it was not uncommon for kiddles to produce a cart-load of fish from a single tide", with each kiddle being emptied twice a day. ${ }^{99}$ We should thus envisage many hundreds of cart-loads of fish per day being caught by the fixed fishing structures around the Thames Estuary and tidal river, augmenting the quantities taken by nets worked from boat and shore, and by line fishing. The concern of the London authorities for the negative effect that the operation of all these fixed structures may have had upon fish stocks is therefore perhaps understandable. Their attempts to control or remove them must be seen, however, as part of a Europe-wide movement by central and local authorities to intervene in human exploitation of the natural environment. Among other rulers, the kings of France repeatedly attempted to combat what they perceived, in Hoffmann's encaspulation, as the "overfishing, wasteful capture techniques, and sheer human greed" which were damaging fish stocks in the Seine, Marne and other major rivers. ${ }^{100}$

\section{Consumption and marketing in London}

Much of the total estuarine catch was no doubt consumed locally, or in the small towns and villages of north Kent and south Essex, and in larger regional centres such as Canterbury, but a significant if unknowable proportion was destined for sale in London. London represented a concentrated and near-at-hand market for Thames fish, by far the biggest centre of demand in medieval England, with perhaps 80,000 inhabitants in 1300 and c. 50,000 in 1400. ${ }^{101}$ Its demands for foodstuffs were complex, as the city concentrated both poor and middling consumers and the super-rich of the medieval period - aristocrats with London town-houses, senior churchmen and women, and of course the royal court and parliament, periodically resident in the detached suburb of Westminster. The demands generated by the smaller post-Black Death city population may, while less in aggregate, have become still more varied as living standards rose, with a greater relative and perhaps overall demand for better quality and more varied food and drink — wheat bread instead

99. Crump, Bob; Wallis, Steve. "Kiddles...": 41.

100. Hoffmann, Richard C. An Environmental History of Medieval Europe. Cambridge: Cambridge University Press, 2014: 273.

101. Keene, Derek, “Medieval London...": 265. 
of rye and oat bread, ale instead of water, meat more often and of better quality. ${ }^{102}$ Within the realm of fish consumption, this may have boosted the relative and perhaps the aggregate demand for fresh fish. Indeed, it is in the later fourteenth and early fifteenth centuries that the ripiers, overland carriers of fresh plaice and other fish from the Sussex coast to London, become evident in the documentary record. ${ }^{103}$ Thames Estuary fisheries seem likely to have benefitted from the same factors which boosted this trade.

The Thames fishermen of the post-Black Death period certainly looked to London as a major market for their produce. In 1394 the fishermen of the inner estuary communities of Lesnes, Plumstead, Erith, Woolwich and Greenwich had petitioned the crown to be allowed to continue with their fishing traditional activities, using boats, nets and "engines", thereby feeding "all the country around as well as the city of London". ${ }^{104}$ Another petition from c. 1420 complained that the use of trawlnets and fishing-weirs was destroying river-fish so that the fishermen "could no longer supply fish to London so cheaply." ${ }^{105}$ Clearly the fishermen differed amongst themselves as to legitimate methods of fishing, but agreed that the Thames and its estuary were an important source of fish for London. Their testimony agrees with that of travellers like William Worcester who, writing of Foulness (perhaps conflated with Canvey Island), noted in 1478 that "the people of the countryside sell fish, oysters and shellfish in London."106

The records of London are replete with references and regulations regarding the marketing of fish, but only a minority specifically relate to Thames and estuary fish. Fish landed at Billingsgate or Queenhithe could be sold at Old and New Fish Streets (the latter also known as Bridge Street) and from 1283 at the Stocks market centrally located between Cheapside and Cornhill. ${ }^{107}$ Men and women called birlsters were allowed to sell fresh and salted fish from door to door, but were obliged to be constantly on the move through the streets and not adopt a fixed selling place. ${ }^{108}$ In the fourteenth century the city authorities tried to exclude wholesalers and 'regraters' (those who bought to re-sell) from the trade in Thames fish, by ordaining that those who caught the fish should sell them themselves, or through members of their immediate family and servants. An ordinance of c. 1342 forbade the forestalling - intercepting of produce on the way to market - of

\footnotetext{
102. Galloway, James A. “Town and Country...": 113-116

103. Galloway, James A. "Ripiers..."

104. TNA. SC8/22/1061.

105. TNA. SC8/143/7137.

106. Worcestre, William. Itineraries...: 145. Much of Worcestre's description seems appropriate to Foulness, but he describes the island as lying "in the water of Thames, off Hadleigh Castle", which more accurately describes Canvey. Canvey is some $20 \mathrm{~km}$ nearer London than is Foulness.

107. Barron, Caroline M. London in the later Middle Ages: Government and People 1200-1500. Oxford: Oxford University Press, 2004: 52

108. Calendar of Letter-Books Preserved among the Archives of the Corporation of the City of London at the Guildhall, Book G, ed. Reginald R. Sharpe. London: J. E. Francis, 1905: 123, 139.
} 
"salmon, lampreys, dace and other fresh fish taken in the Thames". ${ }^{109}$ More simply, it was decreed in 1379 that "no-one shall buy Thames fish to sell again." ${ }^{110}$ A similar proclamation had been made in 1362 concerning "freshwater fish", but these had included smelt and flounder. ${ }^{111}$ A comparable provision had been applied to oysters, mussels and whelks in the late thirteenth century Ordinance of the Fishmongers. ${ }^{112}$

Restrictions were also placed on the locations where Thames fish could be sold: the conduit below the wall of St Margaret's Church, Bridge Street and beneath the wall of St Mary Magdalene's Church in Old Fish Street were the only places authorised by the 1379 ordinance. In 1388 fish caught upstream and downstream of London Bridge were treated differently: all the peters taking fish to the east (downstream) of the bridge were to stand in Cornhill to sell them, while those with fish from the west (upstream) should sell them beside the conduit in Cheapside. ${ }^{113}$ In 1414 we hear that "shotfish" (fish taken after spawning) caught in the Thames were to be sold at London Bridge beside the wall of St Mary Magdalene's. ${ }^{114}$ Whiting caught in the Thames Estuary and brought to the city by boat were ordered in 1418 to be sold wholesale at the quay and then carried to Fish Street for retailing. It was envisaged, however, that fishmongers might be drawn to other markets where fish was displayed for sale, including the estuary ports of Barking, Northfleet and Dartford. ${ }^{115}$

It is undoubtedly true that London's fishmongers were, by the later middle ages at least, primarily interested in the trade in preserved marine species, mostly herring and cod, rather than in fresh fish from the Thames and its estuary, even if the abovenoted regulations would in theory have excluded them from buying up and retailing the latter. London's fishmongers constituted a wealthy grouping of merchants, with diverse interests, but whose central activities remained in the fish trade in the later middle ages. The fishmongers had interests in Yarmouth, including fish-houses and curing facilities, tapping into that port's lucrative herring fishery to obtain supplies for London. ${ }^{116}$ Debt cases from the fifteenth century indicate that they also had strong commercial connections with, Scarborough, Boston (Lincolnshire), North Norfolk and the Sussex coast. ${ }^{117}$ Trade in stockfish (dried cod) from Scandinavia was handled by the stockfishmongers, who maintained a separate identity for much of

\footnotetext{
109. Calendar of Letter-Books Preserved among the Archives of the Corporation of the City of London at the Guildhall, Book F, ed. Reginald R. Sharpe. London: J. E. Francis, 1904: 141.

110. Memorials of London ...: 436.

111. Calendar of Letter-Books Preserved among the Archives of the Corporation of the City of London at the Guildhall, Book G...: 139.

112. Liber Albus...: III, 152.

113. Memorials of London ...: 508.

114. Wright, Laura. Sources...: 92.

115. Liber Albus...: I, 373. These markets might, of course, have handled fish from more remote waters as well as estuary fish.

1 16. Kowaleski, Maryanne. “Commercialization of the Sea Fisheries...": 187; Keene, Derek, "Medieval London...": 275.

117. Colson, Justin R. Local communities in fifteenth century London: Craft, parish and neighbourhood. London: Royal Holloway-University of London (PhD Dissertation), 201 1: 157-158.
} 
the later middle ages and acquired the bulk of their supplies from merchants of the Hanse. ${ }^{118}$

The growth of urban markets is considered to be one of the key factors in the development in the long-distance trade in preserved fish - principally herring and cod- reflected archaeologically in the "fish-event horizon" of c. 1000 A.D. ${ }^{119}$ The quantity of fish bones recovered from archaeological sites increases rapidly at this time, and a marked shift is found in the balance of species represented, away from freshwater and migratory species and towards the marine herring and cod families. An increasing quantity of bones, and an increasing proportion of marine taxa, is noticed earliest in urban contexts, and is then seen to diffuse into urban hinterlands and more purely rural contexts where herring, for instance, became a common food provided for harvest workers in some regions. Historians, meanwhile, have identified an eleventh and twelfth century intensification and commercialisation of coastal and marine fishing — especially for herring — from Scandinavia to England and Flanders. ${ }^{120}$

The fish-bone evidence from London has been examined by Orton to test the hypothesis that the rise in consumption of preserved fish from a distance was stimulated and prefigured by a decline in the availability of freshwater/diadromous and migratory species. He concludes that this was not the case, and that a possible (but far from certain) decline in the occurrence of these species follows rather than precedes the appearance of large quantities of herring and cod bones in the record. ${ }^{121}$ The supply of cod to London does appear to show a significant shift in provenance over time. Isotopic evidence suggests that while the southern North Sea was initially the major source of supply for cod consumed in London, after the middle of the thirteenth century Arctic Norway and the north Atlantic became dominant. ${ }^{122}$ Again, it cannot be certain whether this represents a substitution for depleted local supplies, or a major supplement to a continuing supply from the southern North Sea; given small sample sizes, much uncertainty as yet attaches to the conclusions of this fascinating research.

\footnotetext{
118. Colson, Justin R. “Negotiating merchant identities: the Stockfishmongers and London's companies merging and dividing, c. 1450-1550", Medieval Merchants and Money: Essays in Honour of James L. Bolton, Martin Allen, Matthew Davies, eds. London: Institute of Historical Research, 2016: 15.

119. Barrett, James H.; Locker, Alison M.; Roberts, Callum M. “Dark Age economics revisited: The English fish bone evidence AD 600-1600". Antiquity, 78 (2004): 618-636.

120. Hoffman, Richard C. "Carp, cods, connections: new fisheries in the medieval European economy and environment", Animals in Human Histories, Mary J. Henninger-Voss, ed. Woodbridge: Boydell and Brewer, 2002: 19-20.

121. Orton, David C. “Catch Per Unit Research Effort: Sampling Intensity, Chronological Uncertainty, and the Onset of Marine Fish Consumption in Historic London". Open Quaternary, 3 (2017): 13. The chronological pattern of overall fish bone find-density data is shown to be difficult to interpret, probably because of changing depositional practices, and the "frequency [of freshwater/diadromous/migratory species] relative to other classes suggests at most a subtle decline". Orton, David C. "Catch Per Unit...": 15 (my italics).

122. Orton, David C.; Locker, Alison M.; Morris, James; Barrett, James H. "Fish for London". Cod and Herring: the Archaeology and History of Medieval Sea Fishing, James H. Barrett, David C. Orton, eds. Oxford: Oxbow Books, 2016: 205-214.
} 
It is, moreover, clear that fish caught more locally continued to form an important element of consumption. Documentary sources bearing directly on the consumption of fish within London (rather than the regulation of its marketing) are scanty and biased towards wealthy consumers. However, household accounts and related documents clearly show that estuarine, migratory and fresh-water species, together with fresh marine fish, were widely available for purchase in the city. The early thirteenth century diet account which survives for a London churchman, probably a prebendary of St. Pauls, includes many purchases of fresh or semi-fresh fish and shell-fish likely to be of estuarine and riverine provenance, including smelt, salmon, eels, lampern, lamprey, dace and many purchases of whiting, as well as herring, haddock and plaice. ${ }^{123}$ A great lord residing in London for a session of Parliament in 1300 purchased an array of fresh fish in addition to salted fish, stockfish and the flesh of a dolphin or other cetacean; they included flounder, eels and lampern, together with shellfish (oysters and whelks). ${ }^{124}$ Religious rules regarding fasting and diet in principle required abstinence from meat, and hence favoured fish consumption, on many days of the year, although by the later middle ages these rules were mitigated by all sorts of exemptions and qualifications. Nevertheless, the meals served up by the Kitchener of Westminster Abbey c. 1500 included an estimated 10,800 kg of fish, of which roughly half was made up by members of the cod family, including as stockfish ( $12 \%$ of the total). Herring supplied $8 \%$ of the estimated total by weight, freshwater dace and roach accounted for a further $7 \%$ and eels for $4.5 \%$. Whiting amounted to an impressive $2,158 \mathrm{~kg}$, or $23 \%$ of the total, making it second in importance overall to the gadids. ${ }^{125}$ It featured particularly strongly in meals served in the abbey refectory during winter, just the period when immature whiting were abundant in the outer Thames Estuary. ${ }^{126}$

These findings sit well with the fish-bone evidence from London archaeological sites, where whiting is very prominent right through the later medieval period. Some other estuarine species well-represented in the archaeological record seem to have been less prominent in the monastic diet, and may have been more commonly consumed by lay people, including the less well-to-do. Smelt constitutes one of the commonest species recovered throughout the later medieval period and into the sixteenth century. ${ }^{127}$ Flat-fish bones similarly occur in quantity throughout the medieval period, and would have included estuarine flounder as well as plaice from the sea coast. Eel bones are found in later medieval deposits, although less prominently than in earlier centuries. Sprats, caught inter alia at the mouth of the estuary are common at some $13^{\text {th }}$ and $14^{\text {th }}$ century London sites. ${ }^{128}$ Meanwhile,

123. Household Accounts from Medieval England, ed. Christopher M. Woolgar. Oxford: Oxford University Press, 1993: 118-126.

124. Household Accounts...: 170-173.

125. Harvey, Barbara. Living and Dying in England 1100-1540: the Monastic Experience. Oxford: Oxford University Press, 1993:40-42, 48.

126. Wheeler, Alwyne. Tidal Thames...: 178.

127. Serjeantson, Dale; Woolgar, Christopher M. "Fish consumption...": 123.

128. Serjeantson, Dale; Woolgar, Christopher M. “Fish consumption...": 110-114. 
the "ubiquitous oyster, mussel and cockle shells" uncovered at the $13^{\text {th }}$ century site at No. 1 Poultry, in the heart of the medieval city, "illustrate the reliance upon shellfish." 129

\section{Conclusion}

The evidence presented in this paper makes clear the continuing significance of the Thames Estuary fisheries throughout the later middle ages. The great volume of documentary references to fishing practices and species caught, and the frequency of attempts by London's authorities to regulate the same, point to the value which Thames fish had for consumers, traders and of course for the fishing communities themselves. While prized species like salmon, lamprey and even sturgeon were caught, it is clear that the most important elements of the fishery lay with those species caught in bulk, for mass consumption, including smelt, flounder and eel. Other more marine species including sprat, bass, whiting and herring were caught in quantity around the outer estuary, in weirs and kiddles as well as in nets drawn by boat, together with shellfish dredged off the estuary shores, and all these contributed to London's supply as well as feeding local populations. The estuarine fisheries were commercialised and responded to the pull of urban markets and in particular that of the major centre of consumption represented by the city of London. The rise of the bulk trade in preserved fish, brought in from eastern English ports and from more distant waters, clearly did not eliminate the estuarine fisheries, which display a notable dynamism during the later fourteenth and fifteenth centuries. The fisheries of the tidal Thames and the estuary can thus be seen as a basic stratum of significant fishing activity which continues throughout the medieval period, overlain later by the import of preserved fish, representing fishing activity in somewhat more distant (eastern England) and then considerably more distant (Scandinavia, Iceland etc.) waters. Indeed, changing living standards in the aftermath of the Black Death may have expanded the market for fresh, locally caught fish in absolute if not in relative terms, as more "middling" urban consumers — above all in London- aspired to consume food once largely the preserve of their social betters.

129. Thomas, Christopher. The Archaeology of Medieval London. Stroud: Sutton, 2002: 73 


\section{Appendix. Latin names of fish species mentioned in the text}

\begin{tabular}{|c|c|}
\hline Barbel & Barbus barbus \\
\hline Bass & Dicentrarchus labrax \\
\hline Brill & Scophthalmus rhombus \\
\hline Chub & Squalius cephalus \\
\hline Cod & Gadus morhua \\
\hline Dab & Limanda limanda \\
\hline Dace & Leuciscus leuciscus \\
\hline Eel & Anguilla anguilla \\
\hline Flounder & Platichthys flesus \\
\hline Garfish & Belone belone \\
\hline Gudgeon & Gobio gobio \\
\hline Gurnard & Eutrigla gurnardus \\
\hline Haddock & Melanogrammus aeglefinus \\
\hline Herring & Clupea harengus \\
\hline Lamprey & Petromyzon marinus \\
\hline Mullet & Mugilidae \\
\hline Plaice & Pleuronectes platessa \\
\hline Roach & Rutilus rutilus \\
\hline Salmon & Salmo salar \\
\hline Shad & Alosa alosa \\
\hline Smelt & Osmerus eperlanus \\
\hline Sole & Solea solea \\
\hline Sprat & Sprattus sprattus \\
\hline Sturgeon & Acipenser $s p$ \\
\hline Tench & Tinca tinca \\
\hline Whiting & Merlangius merlangus \\
\hline
\end{tabular}

